\title{
Feeding of juvenile white shrimp Penaeus setiferus: periodic or continuous?
}

\author{
Teresa Ann McTigue ${ }^{1, *}$, Robert J. Feller ${ }^{1,2,3}$ \\ ${ }^{1}$ Marine Science Program, ${ }^{2}$ Department of Biology, and ${ }^{3}$ Belle W. Baruch Instifute for Marine Biology and Coastal Research, \\ University of South Carolina, Columbia, South Carolina 29208, USA
}

\begin{abstract}
Juvenile white shrimp Penaeus setiferus were collected every $3 \mathrm{~h}$ during two 48 h sampling periods (August 20 to 22 and September 14 to 16, 1985), in the tidal creeks and surrounding marsh areas of North Inlet, South Carolina, USA. Weight of gut contents material relative to shrimp body weight was measured to determine if gut fullness remained constant through time or if variations were correlated with changes in light and tidal levels. All foreguts of the shrimp sampled always contained food and no strong temporal, tidal, or light trends in fullness were evident. It is not known whether this indicated continuous feeding by the shrimp or merely reflects changes in their gut clearance rates. A maximum in gut fullness at sunrise during both $48 \mathrm{~h}$ periods may have resulted from increased feeding rates at that time. Although shrimp captured in September were on average larger $(50.4$ vs $41.6 \mathrm{~mm}$ carapace length), they had approximately the same mass of food in the guts per unit body weight as those collected in August.
\end{abstract}

\section{INTRODUCTION}

Previous studies of the diurnal feeding periodicities of estuarine organisms indicate that the 2 most influential cues for feeding seem to be cycles in tide and light (Roger 1975, Weisberg et al. 1981, Baars \& Oosterhuis 1984, Bowman 1984, Talbot \& Baird 1985). By feeding at higher tidal elevations in the marsh, an organism makes available to itself a variety of prey either absent or less abundant on the intertidal or subtidal creek bottoms. Studies of gut contents have shown fish regularly feed on prey which inhabit the marsh surface (Fritz 1974, Kneib \& Stiven 1978). Feeding habits cued to the natural, diel light cycle may allow an organism to avoid predation, increase contact with preferred food items, or reduce competition for a limited food resource (Doble \& Eggers 1978, Wetzel 1983, Baars \& Oosterhuis 1984).

The postlarvae of Penaeus setiferus appear to utilize the salt marsh as a nursery. While the time of postlarval recruitment varies slightly with location, $P$. setiferus typically first appears in South Carolina estuaries during June or July (Pérez Farfante 1969, Copeland \&

\footnotetext{
- Present address: Marine Biology Department, Fort Crockett Campus, Bldg 3311, Texas A \& M University, Galveston, Texas 77551, USA
}

Bechtel 1974, Weinstein 1979, Williams 1984). White shrimp seem to prefer soft, muddy substrates, moving initially far upcreek toward lower salinities. As the shrimps grow, they move to more saline areas, finally returning to the ocean as they approach adulthood and enter the fishery (Williams 1984). Little, though, is known of their feeding habits during their salt marsh residence. Identification of gut contents even under high magnification is hampered because shrimp shred and grind their food using their mouthparts and a gastric mill or proventriculus. Most often, the gut contents consist of unidentifiable debris and hard parts which resist the shredding process. It has been widely accepted, however, that white shrimp are opportunistic bottom-feeders, consuming whatever material is available (Williams 1955, Young 1959, Darnell 1961). Hunter \& Feller (1987) demonstrated that both $P$. setiferus and Penaeus aztecus utilize intertidal or subtidal marsh areas as feeding grounds and that there are seasonal changes in the diets of the shrimp. The diet of brown shrimp also varied as a function of food availability and included animals and plant material as well as plankton (Gleason \& Wellington 1988)

Since white shrimp seem to be opportunistic feeders, both animal prey and plant material should be found in their digestive systems. By considering changes in the entire mass of food consumed, overall temporal feeding 
patterns should be evident. This study was designed to determine if the amount of material in the gut of Penaeus setiferus remains constant over a $24 \mathrm{~h}$ period. Alternatively, if the gut contents weights change through time, could a feeding periodicity be detected and related to changes in tidal height or light level?

\section{MATERIALS AND METHODS}

Study site and collection methods. Penaeus setiferus were collected every $3 \mathrm{~h}$ during two $48 \mathrm{~h}$ periods. During the first $48 \mathrm{~h}$ sampling period (August 20 to 22 . 1985), the daytime high tide coincided with the time of maximum solar radiation. During the second sampling period about a month later (September 14 to 16, 1985), the daytime low tide occurred at the approximate solar maximum (Fig. 1). This alternation of conditions
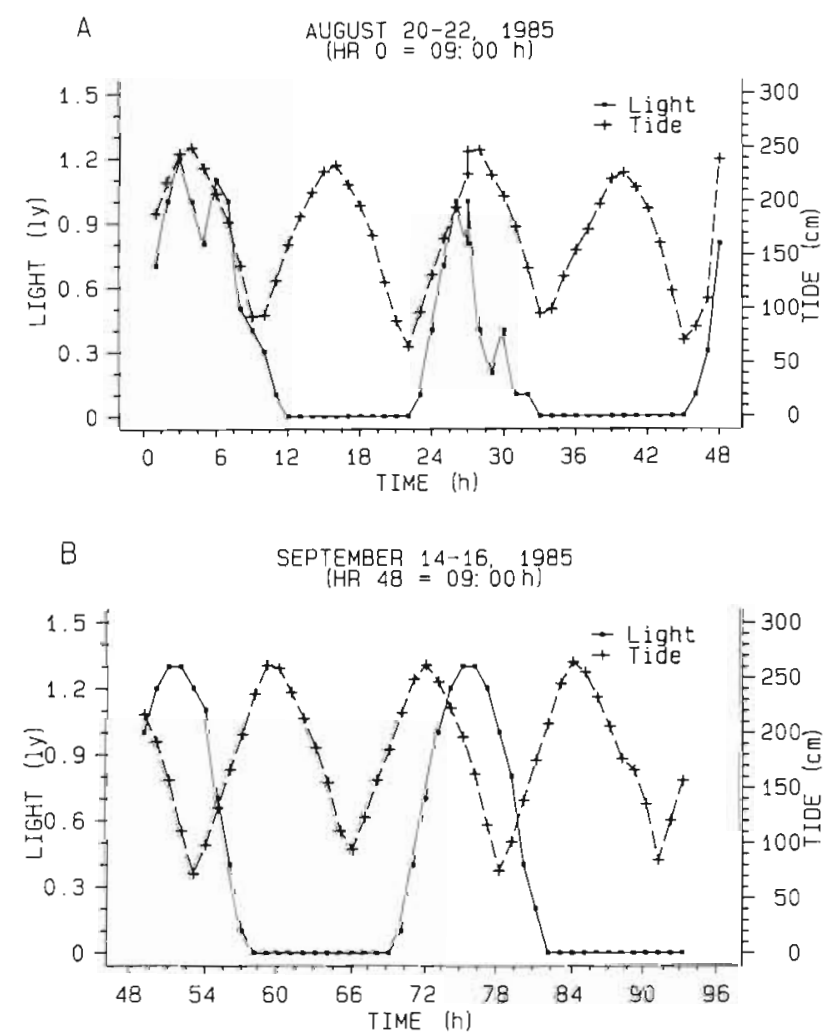

Fig. 1. Tidal heights and light levels during the $48 \mathrm{~h}$ sampling periods on (A) 20 to $22 \mathrm{Aug}$ and (B) 14 to $16 \mathrm{Sep}, 1985$, at

Oyster Landing in North Inlet, South Carolina, USA

allowed a greater number of tidal and light combinations to be sampled and compared. Collections took place in the tidal creeks of North Inlet near Georgetown, South Carolina, USA $\left(37^{\circ} 20^{\prime} \mathrm{N}\right.$, $79^{\circ} 10^{\prime} \mathrm{W}$ ). The majority of the shrimp were captured in the Oyster Landing area, but due to extremely high tidal levels and low shrimp abundance during September, the collection area was expanded to include a portion of nearby Town Creek.

Several types of collection equipment were used depending on the tidal height. At low water levels, seines were employed, with a mesh size of either $6.4 \mathrm{~mm}(1 / 4 \mathrm{inch})$ or $15.8 \mathrm{~mm}(5 / 8$ inch). When seining became impossible, small meshed cast nets with either a 152 or $182 \mathrm{~cm}$ ( 5 or $6 \mathrm{ft}$ ) diameter were used. During periods of exceptionally high water during the September sampling, an otter trawl (480 cm length) with a $6 \mathrm{~mm}$ codend mesh was towed by a motorboat to collect shrimp in Town Creek. Totals of 194 and 142 shrimp were collected in the August and September sampling periods, respectively.

Once captured, the gastric mill and hepatopancreas from each shrimp was removed with forceps and immediately frozen on dry ice in the field, separate from the body. Later, each shrimp was thawed, weighed, and carapace length measured from the tip of the rostrum to the posterior edge of the dorsal surface of the carapace. The intact gut (gastric mill plus hepatopancreas) was weighed while frozen and then again when empty ( $\pm 0.1 \mathrm{mg}$ ) after thawing, and the contents weight calculated by difference. The gut contents were easily removed by applying pressure along the length of the gut with forceps. Dry weight of the gut contents could not be determined because other analyses were to be conducted on the same native gut content material. However, a random selection of gut contents samples collected in August was dried to determine the relationship between wet and dry gut contents weights. A strong linear correlation between wet and dry gut contents weights $\left(r^{2}=0.8722, p=\right.$ 0.0001 ) indicated that wet weight was a reasonably accurate measure of the dry contents of the gut. Total wet body weight was calculated by adding the wet weight of the empty gut wall to the wet weight of the gutless shrimp.

Tidal height and solar radiation levels were obtained from a meteorological station at the Oyster Landing collection site. Periods of high and low tide were arbitrarily defined as occurring $1.5 \mathrm{~h}$ on either side of the highest and lowest levels measured. The 4 light intensities were defined as: night $=0$ langleys (ly), morning and evening $>0$ but $\leq 0.4 \mathrm{ly}$, and day $>0.4 \mathrm{ly}$.

Statistical analysis. Gut contents weights were transformed to a $\log _{10}$ scale. Homogeneity of variances of gut contents weights among sampling times was tested using an F-max test (Sokal \& Rohlf 1981). Gut contents weight relative to total body weight was used as an index of feeding which took place during the previous $3 \mathrm{~h}$ sampling interval. An analysis of covariance (ANCOVA) was performed on the transformed gut contents data from each 48 h period (using total shrimp 
body wet weight as the covariate) to determine if changes in wet gut contents weight were related to changes in tidal level or light intensity. Mean gut contents weights adjusted for body weight of the shrimp were provided by an estimation of the leastsquare means, yielding mean weights that would be expected if all shrimp were the same weight. The ANCOVA design was completely balanced (SAS Institute Inc. 1982). Individual observations of gut contents weight were adjusted for body weight by adding the least-square mean for a sampling time to the statistical residual of each individual shrimp's gut contents weight within that sampling interval. Transformed adjusted gut contents weights were linearly regressed against both tidal height and light level for each $48 \mathrm{~h}$ period. This differed from the ANCOVA in that morning and evening values were not distinguished.

A nonparametric 1-sample runs test for randomness (Daniel 1978) was performed for each $48 \mathrm{~h}$ period to determine if variations in mean gut contents weight (adjusted for body weight) for each 3 h sampling interval from the overall $48 \mathrm{~h}$ mean occurred randomly throughout the sampling. The runs test was also applied to test whether differences between the adjusted mean for the sampling interval $t=n$ and the mean of the next interval $t=n+1$ were random. In other words, were the directional changes of an interval mean relative to the previous mean random?

Least-square mean gut contents weights were calculated for each combination of tidal stage and light level sampled during the 2 separate $48 \mathrm{~h}$ periods. The method of linear contrasts (Sokal \& Rohlf 1981) was used to compare transformed, adjusted mean gut contents weights at tidal stages that occurred under the same light level and at light levels that occurred at the same stage of the tide. To determine if there was a linear relationship between the size of a shrimp and the relative weight of material held in its proventriculus, the detransformed, adjusted gut contents weights were regressed against their respective shrimp wet body weights.

To eliminate the chance that variation in gut contents weights within each body weight was due to the pooling of all time intervals for each sampling period, the adjusted gut contents weights from the time interval with the highest sample size for each $48 \mathrm{~h}$ period were regressed against their corresponding shrimp body weights.

\section{RESULTS}

Although there were wide ranges in the weights of gut contents material, none of the proventriculi of Penaeus setiferus were ever empty. Gut contents weights increased and decreased without pattern dur- ing both the August and September 48 h study periods. Nonparametric runs tests on the detransformed, adjusted gut contents weights indicated that neither variations from the mean adjusted gut contents weight nor variations from the previous sample time exhibited a significant pattern during either 48 h study (Fig. 2).
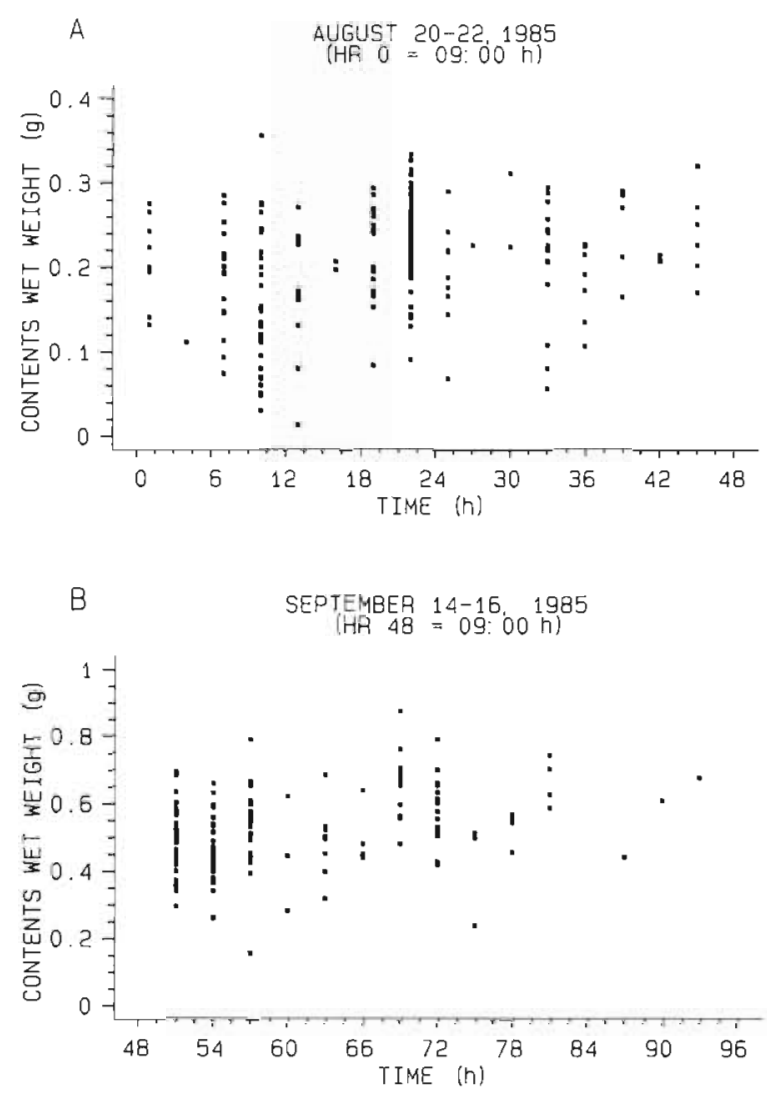

Fig. 2. Penaeus setiferus. Detransformed, adjusted wet gut contents weights of shrimp collected during the two $48 \mathrm{~h}$ sampling periods

Eleven balanced comparisons were made by linear contrasts from the August collection. The only significant contrasts were that greater than average amounts of food occurred in shrimp at low tide and in the morning $\left(\mathrm{H}_{1}\right.$, Table 1). During September when fewer balanced contrasts could be made, morning gut contents weights were significantly greater than those from the evening at flood tide $\left(\mathrm{H}_{1}\right.$, Table 2). However, the analysis of covariance performed on the gut contents weights (using body weight as the covariate and tidal stage and light level as main effects) showed slightly different results for the 2 sampling periods. There was a significant effect of light level in August with weak interaction occurring between tidal stage and light level (Table 3A). In September the effect of light level was again significant (Table $3 B$ ). When morning samples were available for comparison with 
Table 1 Penaeus setiferus. (A) Combinations of light and tide levels available for comparison by linear contrasts during the $48 \mathrm{~h}$ sampling, Aug 20 to 22,1985 . $U_{1}$ to $U_{10}$ denote cell means of $\log _{10}$ transformed, adjusted gut contents weights. Dash indicates combination did not occur during sampling period (B) Null hypotheses and linear contrast results assessing various combinations of tide and light; ( $p$-values; significance level: $p=0.05$ )

\begin{tabular}{lccccc}
\hline \multirow{2}{*}{ Light } & \multicolumn{4}{c}{ Tide } \\
& Ebb & Low & Flood & High \\
\hline Morning & - & $\mathrm{U}_{9}$ & - & - \\
Day & $\mathrm{U}_{1}$ & - & $\mathrm{U}_{4}$ & $\mathrm{U}_{6}$ \\
Evening & $\mathrm{U}_{2}$ & $\mathrm{U}_{8}$ & - & - \\
Night & $\mathrm{U}_{3}$ & $\mathrm{U}_{10}$ & $\mathrm{U}_{5}$ & $\mathrm{U}_{7}$ \\
\hline
\end{tabular}

B. $\mathrm{H}_{1}$ : morning gut contents weights are not significantly different from evening gut contents weights at low tide. Contrast: $U_{9}=U_{8} ;(0.0001)$

$H_{2}$ : evening means do not differ significantly from night means at ebb tide and low tide. Contrast $\left(U_{2}+U_{B}\right) / 2=\left(U_{3}+U_{10}\right) / 2 ;(0.6506)$

$\mathrm{H}_{3}$ : day means do not significantly differ from night means at ebb, flood, or higt tide. Contrast: $\left(\mathrm{U}_{1}+\mathrm{U}_{4}+\mathrm{U}_{6}\right) / 3=\left(\mathrm{U}_{3}+\mathrm{U}_{5}+\mathrm{U}_{7}\right) / 3_{i}(0.6357)$

$\mathrm{H}_{4}$ : morning means are not significantly different from night means at low tide Contrast: $U_{9}=U_{10}$ i (0.2093)

$\mathrm{H}_{5}$ : ebb tide means are not significantly different from means at hight tide under day and night conditions. Contrast: $\left(\mathrm{U}_{1}+\mathrm{U}_{3}\right) / 2=\left(\mathrm{U}_{6}+\mathrm{U}_{7}\right) / 2$; (0.9780)

$\mathrm{H}_{6}$ : ebb and low tide means do not differ during the evening and night. Contrast: $\left(\mathrm{U}_{2}+\mathrm{U}_{3}\right) / 2=$ $\left(\mathrm{U}_{8}+\mathrm{U}_{10}\right) / 2_{i}(0.0407)$

$\mathrm{H}_{7}$ : low and flood tide means do not differ significantly at night. Contrast: $\mathrm{U}_{5}=\mathrm{U}_{10 ;}(0.0598)$

$\mathrm{H}_{8}$ : flood and high time means do not differ significantly during the day and night. Contrast: $\left(\mathrm{U}_{4}+\mathrm{U}_{5}\right) / 2=\left(\mathrm{U}_{6}+\mathrm{U}_{7}\right) / 2 ;(0.4312)$

$\mathrm{H}_{9}$ : ebb and flood tide means do not differ significantly during the day and night. Contrast: $\left(\mathrm{U}_{1}+\mathrm{U}_{3}\right) / 2=\left(\mathrm{U}_{4}+\mathrm{U}_{5}\right) / 2 ;(0.1384)$

$\mathrm{H}_{10}$ : low and high tide means do not differ significantly at night. Contrast: $\mathrm{U}_{7}=\mathrm{U}_{10} ;(0.0598)$

$\mathrm{H}_{11}$ : day and evening means do not differ significantly at ebb tide. Contrast: $U_{1}=U_{2 i}(0.2571)$

other light levels, gut contents weight tended to be somewhat higher - but not significantly so - in the morning than during other light levels (Fig. 3). Linear regressions performed between the detransformed, adjusted gut contents weights with both tidal and light levels explained at most only $6 \%$ of the variance between these variables in either August or September

Shrimp size increased between the 2 studies. In August, average carapace length was $41.6 \mathrm{~mm}$, whereas September shrimp averaged $50.4 \mathrm{~mm}$ and had twice the body weight of August shrimp (Table 4). In
Table 2. Penaeus setiferus. (A) Combinations of light and tide levels available for comparison by linear contrasts during the 48 h sampling, Sep 14 to 16,1985 . $U_{1}$ to $U_{10}$ denote cell means of $\log _{10}$ transformed, adjusted gut contents weights. Dash indicates combination did not occur during sampling period. (B) Null hypotheses and linear contrast results assessing various combinations of tide and light; ( $p$-values; significance level: $p=0.05$ )

\begin{tabular}{lcccc}
\hline \multirow{2}{*}{ Light } & \multicolumn{4}{c}{ Tide } \\
& Ebb & Low & Flood & High \\
\hline Morning & - & - & $\mathrm{U}_{4}$ & - \\
Day & $\mathrm{U}_{1}$ & $\mathrm{U}_{7}$ & - & $\mathrm{U}_{5}$ \\
Evening & - & - & $\mathrm{U}_{3}$ & - \\
Night & $\mathrm{U}_{2}$ & $\mathrm{U}_{8}$ & - & $\mathrm{U}_{6}$ \\
\hline
\end{tabular}

B. $\mathrm{H}_{1}$ : morning and evening mean gut contents weights do not differ significantly at flood tide. Contrast: $\mathrm{U}_{3}=\mathrm{U}_{4} ;(0.0211)$

$\mathrm{H}_{2}$ : day and night meand do not differ significantly during ebb, flood, and high tides. Contrast: $\left(\mathrm{U}_{1}+\mathrm{U}_{5}+\mathrm{U}_{7}\right) / 3=\left(\mathrm{U}_{2}+\mathrm{U}_{6}+\mathrm{U}_{8}\right) / 3 ;(0.3284)$

$\mathrm{H}_{3}$ : ebb and low tide means do not differ significantly during day and night. Contrast: $\left(\mathrm{U}_{1}+\mathrm{U}_{2}\right) / 2$ $=\left(\mathrm{U}_{7}+\mathrm{U}_{8}\right) / 2_{i}(0.6812)$

$\mathrm{H}_{4}$ : ebb and high tide means do not differ significantly at day and night Contrast: $\left(\mathrm{U}_{1}+\mathrm{U}_{2}\right) / 2=$ $\left(\mathrm{U}_{5}+\mathrm{U}_{6}\right) / 2 ;(0.7507)$

$\mathrm{H}_{5}$ : low and high tide means do not differ significantly during the day and night. Contrast: $\left(\mathrm{U}_{5}+\mathrm{U}_{6}\right) / 2=\left(\mathrm{U}_{7}+\mathrm{U} 8\right) / 2 ;(0.9819)$

Table 3. Penaeus setiferus. Analysis of covariance on $\log _{10}$ transformed gut contents weights (dependent variable) with $\log _{10}$ body weights as the covariate for the $48 \mathrm{~h}$ sampling periods, (A) Aug 20 to 22 and (B) Sep 14 to 16, 1985. Significance level: $p=0.05$

\begin{tabular}{|lrrr|}
\hline \multicolumn{1}{c}{ Source } & d.f. & $F$ & p-value \\
\hline A. Body weight & 1 & 265.53 & 0.0001 \\
Tidal height & 2 & 2.20 & 0.0890 \\
Light level & 3 & 6.04 & 0.0006 \\
Tide $\times$ Light & 3 & 2.57 & 0.0557 \\
Error & 3 & & \\
& 194 & & \\
B. Body weight & 1 & 375.28 & 0.0001 \\
Tidal height & 3 & 0.11 & 0.8978 \\
Light level & 2 & 3.20 & 0.0437 \\
Tide $\times$ Light & 2 & 2.04 & 0.1336 \\
Error & 142 & & \\
\hline
\end{tabular}

order to compare the fullness of shrimp from both $48 \mathrm{~h}$ samplings, body sizes were adjusted to the grand mean weight of all shrimp collected in the study. The overall mean adjusted gut contents weights were $0.207 \mathrm{~g}$ in August and $0.532 \mathrm{~g}$ a month later. Regressions performed to determine if there was a linear relationship between the adjusted gut contents weights and body 
Table 4. Penaeus setiferus. Physical and biological variables measured during $48 \mathrm{~h}$ periods, Aug 20 to 22 and Sep 14 to 16. 1985

\begin{tabular}{|lcc|}
\hline Variable & Aug & Sep \\
\hline Mean air temperature & $25.7^{\circ} \mathrm{C}$ & $19.2^{\circ} \mathrm{C}$ \\
Mean water temperature & $29.7^{\circ} \mathrm{C}$ & $22.8^{\circ} \mathrm{C}$ \\
$\begin{array}{l}\text { Mean shrimp body weight } \\
\text { Mean carapace length }\end{array}$ & $\begin{array}{l}4.57 \mathrm{~g} \\
\text { Mean weight of gut contents } \\
\text { (actual) }\end{array}$ & $16.5 \mathrm{~g}$ \\
$\begin{array}{l}\text { Detransformed, adjusted mean } \\
\text { gut contents weight }\end{array}$ & $0.091 \mathrm{~g}$ & $0.516 \mathrm{gm}$ \\
\hline
\end{tabular}

weights were not significant for either study period or for any of the individual time intervals considered.

\section{DISCUSSION}

At no time during the day or night were Penaeus setiferus foreguts empty, nor could any periodicity in the amount of matter contained in the proventriculus be detected (Fig. 2). Additionally, regressions did not detect a clear relationship between adjusted gut contents weights and either tidal heights or light levels in either $48 \mathrm{~h}$ sampling period (Table 3 ). Since no gut clearance rates have been published for $P$. setiferus, it is uncertain whether this lack of periodic temporal change in gut fullness was due to continuous feeding, differential changes in gut evacuation rates, or simply due to large variance resulting from some unavoidably small sample sizes collected during the highest tide conditions.

It is common for arthropods to alter the rate at which they clear their guts, although the cues to which they respond vary. Murtaugh (1984) demonstrated that Neomysis mercedis varied its gut clearance time with the amount of food available. Under low food conditions, this mysid held consumed material in its digestive tract longer than under high food conditions. Similarly, the cladoceran Daphnia pulex varied its gut contents retention time inversely with the concentration of food in the surrounding water (Geller 1975). Temperature also affects the amount of time it takes for food to pass through an animal. Hexagenia limbata, a mayfly, had different gut clearance rates based on changes in water temperature (Zimmerman \& Wissing 1978). Larval Chaoborus spp., an aquatic insect, did not vary its gut clearance time, but instead varied the time it took to digest matter according to temperature and prey type ingested (Fedorenko 1975).

For shrimp, too, the length of time food remains in the gut depends on the nature of the material. The penaeid gastric mill recirculates and continues to grind matter until it is small enough to pass beyond a large medial tooth which is part of its food grinding mechanism (Young 1959). Hard or dense material may have a longer residence time in the gastric mill due to difficulties in its mechanical breakdown. Before a clear interpretation of feeding intensity can be produced from gut fullness data alone, gut clearance rates need to be investigated under a variety of conditions, such as varied temperatures and food types. Knowledge of gut clearance times would also permit utilization of gut fullness data in the calculation of daily rations for white shrimp. At this time, trends in the adjusted contents weights over time alone provide only a minimum estimate of the amount of food the shrimp consume in a unit of time.

The grinding apparatus in penaeids is less calcified than in other decapods and observation has shown the mouthparts to have less of a mastigatory function than was once thought. Suthers (1984) suggested that the large amounts of sand and shell fragments found in the gut of Penaeus plebejus act as a crop, much like that of a bird. Both white and brown shrimp $(P$. setiferus and $P$. aztecus) use their third maxillipeds to sort material while feeding on algal mats, discarding unwanted particles, but coarse matter is still found in the gut (Condrey et al. 1972). Refractory material used in the grinding process may be difficult to distinguish gravimetrically from the actual food and could make the gut appear full of digesting matter when it actually was not. Presence of non-food items such as this could also account for the absence of empty guts found in this study.

During the August sampling, morning light levels and low tide were important influences on the weight of gut contents found in the shrimp, especially when low tide occurred roughly at dawn or shortly before sunrise (Table 1). When low tide and dawn occur at the same time, the effects of either condition alone could mask the effect of the other. During September, no tidal effect could be demonstrated. The only statistically significant contrast in gut fullness detected was a comparison between morning and evening light levels during the flood tidal stage (Table 2). Since there were no tidal effects demonstrated during the September sampling period, it seems likely that the significant effects observed in August were due to light level and not low tide. The results of the ANCOVAs also support this interpretation (Table 3). When available for comparison, morning gut contents weights were consistently higher than, although not always significantly different from, weights at other times of day at a similar stage of the tide (Fig. 3). This would suggest that, while there is always material in the digestive system white shrimp seem to have an increased amount of food in their guts during the morning. The increase in gut fullness directly after 
A

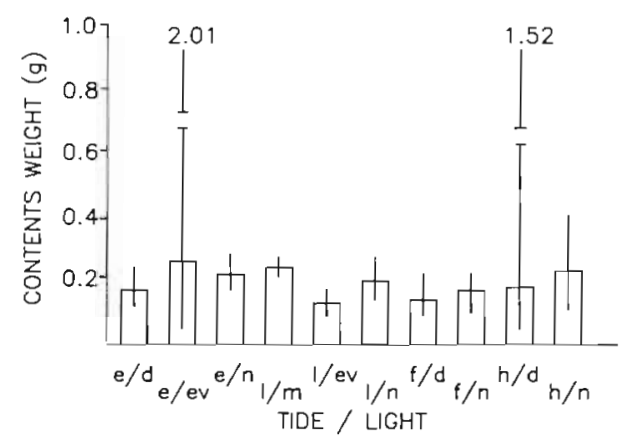

B

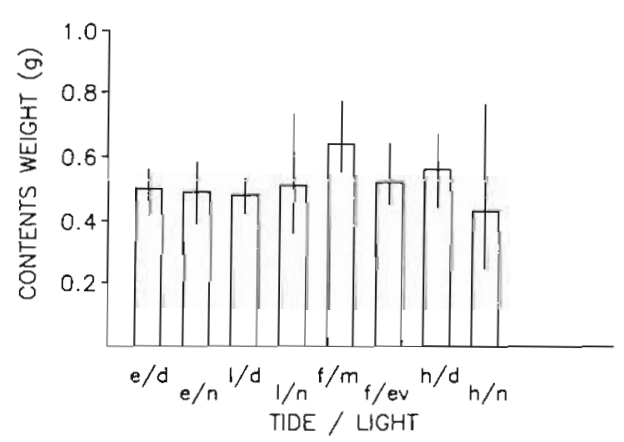

Fig. 3. Penaeus setiferus. Mean values (with $95 \%$ confidence intervals) of detransformed, adjusted gut contents weights of shrimp collected at specific combinations of tidal height and light levels during the two $48 \mathrm{~h}$ samplings. e: ebbtide; $\mathrm{l}$ : lowtide; f: floodtide; h: hightide; m: morning; d: day; ev: evening; $n$ : night

dawn may be a response to increased feeding directly after emergence from the substrate.

There was very little difference in gut contents weight in relation to shrimp size when the 2 sampling periods were compared (Table 3). During September, when larger shrimp were captured, the amount of food in the gut increased only slightly compared to shrimp collected in August. There was not a strong relationship between the relative amount of food in the gut and the weight of the shrimp, probably due to the wide range of contents weights found within each body weight. Without data on gut clearance rates, there was no indication that shrimps of different sizes fed with different intensities.

Factors influencing the feeding pattern of an organism are complex and can inhibit definition of a pattern even when one exists. Juvenile Penaeus setiferus in North Inlet exhibited no clear temporal trend in the increase or decrease of gut contents weights in relation to their body weigths, even though maximum gut contents weights were observed during the morning. Factors responsible for this maximum are unknown, but it may be associated with a change in activity levels between night and day.
Acknowledgements. This study was performed as partial fulfillment of the requirements for a Master of Science degree for the first author. Special thanks are owed the Belle W. Baruch Institute for Marine Biology and Coastal Research for use of their facilities and equipment. Thanks also go to J. Archambault, R. Baldevarona, L. A. Clements, R. Ferguson, B. Hentschel, P. Myer, and G. Zagursky for assisting with field collections and other aspects of the study. This work was supported by the South Carolina Sea Grant Consortium, grant R/CF-10 to RJF. This is contribution No. 734 from the Belle W. Baruch Institute for Marine Biology and Coastal Research.

\section{LITERATURE CITED}

Baars, M. A., Oosterhuis, S. S (1984). Diumal feeding rhythms in North Sea copepods measured by gut fluorescence, digestive enzyme activity and grazing on labelled food. Neth. J. Sea Res. 18: 97-119

Bowman, R. E. (1984). Food of silver hake, Merluccius bilinearis. Fish. Bull. U. S. 82: 21-35

Condrey, R. E., Gosselink, J. G., Bennett, H. J. (1972). Comparison of the assimilation of different diets by Penaeus setiferus and $P$. aztecus. Fish. Bull. U. S. 70: 1281-1292

Copeland, B. J., Bechtel, T. J. (1974), Some environmental limits of six Gulf coast estuarine organisms. Contr. mar. Sci. 18: 169-204

Daniel, W. W. (1978). Applied nonparametric statistics. Houghton Mifflin Co., Boston, p. 53-58

Darnell, R. M. (1961). Trophic spectrum fo an estuarine community, based on studies of Lake Pontchartrain, Louisiana. Ecology 42: 553-568

Doble, B. D., Eggers, D. M. (1978). Diel feeding chronology: rate of gastric evacuation, daily ration, and prey selectivity in Lake Washington juvenile sockeye salmon(Oncorhynchus nerka). Trans. Am. Fish. Soc. 107: 36-45

Fedorenko, A. Y. (1975). Instar and species-specific diets in two species of Chaoborus. Limnol. Oceanogr. 20: 238-249

Frit2, E. S. (1974). Total diet comparison in fishes by Spearman rank correlation coefficient. Copeia 74: 210-214

Geller, W. (1975). Die Nahrungsaufnahme von Daphnia pulex in Abhängigkeit von der Futterkonzentration, der Temperatur, der Körpergröße und dem Hungerzustand der Tiere. Hydrobiol. Suppl. 48: 47-107; cited in Murtaugh (1984)

Gleason, D. F., Wellington, G. M. (1988). Food resources of postlarval brown shrimp (Penaeus setiferus) in a Texas salt marsh. Mar. Biol. 97: 329-338

Hunter, J., Feller, R. J. (1987). Immunological dietary analysis of two penaeid shrimp species from a South Carolina tidal creek. J. exp mar. biol. Ecol. 107: 61-70

Kneib, R. T., Stiven, A. E. (1978). Growth, reproduction, and feeding of Fundulus heteroclitus (L.) on a North Carolina salt marsh. J. exp. mar. Biol. Ecol. 31. 121-140

Murtaugh, P. A. (1984). Variable gut residence time: problems in inferring feeding rate from stomach fullness of a mysid crustacean. Can. J. Fish. Aquat. Sci. 41. 1287-1293

Pérez Farfante, I. (1969). Western Atlantic shrimps of the genus Penaeus. Fish. Bull. U. S. 67: 461-591

Roger, C. (1975). Rythmes nutritionnels et organisation trophique d'une population de crustacés pélagiques (Euphausiacea). Mar Biol. 32: 365-378

SAS Institute Inc. (1982). SAS user's guide: statistics. SAS Institute Inc, Cary, N. C., p. 139-199

Sokal, R. R., Rohlf, F. J. (1981). Biometry. W. H. Freeman and Co., San Francisco 
Suthers, I. M. (1984). Functional morphology of the mouthparts and gastric mill in Penaeus plebejus Hess (Decapoda: Penaeidea). Aust. J. mar Freshw. Res. 35: 785-792

Talbot, M. M. J.-F., Baird, D. (1985). Feeding of the estuarine round herring Gilchristella aestuarius $(\mathrm{G}$ \& $\mathrm{T})$ (Stolephoridae). J. exp. mar Biol. Ecol. 87: 199-214

Weinstein, M. P. (1979). Shallow marsh habitats as primary nurseries for fishes and shellfish, Cape Fear River, North Carolina. Fish. Bull. U. S. 77: 339-357

Wetzel, R. G. (1983). Limnology. W. B. Saunders Co., Philadelphia

This article was presented by Professor K. R. Tenore, Solomons, Maryland, USA
Williams, A. B. (1955). A contribution to the life histories of commercial shrimps (Penaeidae) in North Carolina. Bull. mar. Sci. 5: 116-146

Williams, A. B. (1984). Shrimps, lobsters, and crabs of the Atlantic Coast of the Eastern United States, Maine to Florida. Smithsonian Institution Press, Washington, D. C.

Young, J. H. (1959). Morphology of the white shrimp Penaeus setiferus (Linnaeus 1758). Fish. Bull. U.S. 59: 1-168

Zimmerman, M. C., Wissing, T E. (1978). Effects of temperature on gut-loading and gut-clearing times of the burrowing mayfly, Hexagenia limbata. Freshwater Biol. 8: $269-277$

Manuscript received: July 11, 1988

Revised version accepted: January 2, 1989 